\title{
China-Pakistan Relations: With Reference to the Political Economy
}

\author{
*Prof. Dr. Mohammad Ahmed Qadri \\ Department of Political Science, University of Karachi \\ **Suwaibah Qadri \\ Research Scholar \\ Department of Political Science, University of Karachi
}

\begin{abstract}
Pakistan has a long and strong relationship with China, and it will remain their strength due to their geo-political requirements. A close identity of socio-political views and mutual interests in the political economy remain the centre-point of bilateral ties. Since 1962 war, Pakistan has supported China in important matters regarding national and international issues. Pak-China also collaborated extensively in military and economic projects. Pakistan has also served as a conduit for China's influence in the Muslim World. China has pledged to vastly increase their investment in Pakistan's economy and infrastructure. The author of the paper believes that this paper would academically contribute towards Pakistan to promote peace through political economy between China- Pakistan Economic Corridor.

Keywords: geo-political, socio-political, China- Pakistan Economic Corridor (CPEC), Pak-China, political economy

DOI: $10.7176 /$ IAGS/74-01

Publication date:July $31^{\text {st }} 2019$

\section{INTRODUCTION:}

Pak-China relationship has a glorious past, [and a] bright future. ${ }^{1}$ Karakoram Highway, the connection between China and Pakistan, is also sometimes referred to as the Eighth Wonder of the World. One of the reasons for this is that the solid ties between these two countries have been built on the fact that there is mutual benefit. Pakistan shares a common border with the People's Republic of China through her Nothern States of Hunza and Gilgit $^{2}$ (about 300 miles). The Chinese ancient traders used to visit the land of the Indus for commercial purposes. Their contributions are more valuable than the merchants in the promotion and exchange of ideas and culture between these two ancient civilizations. ${ }^{3}$ On the other hand, Pakistan has repetitively received help with regional issues because the Pakistan military depends heavily on Chinese armaments and joint projects of both ecomilitaristic importance.

Diplomatic relations between Pakistan and China were established as early as May of 1951 . The diplomatic relations between the two countries were established on the basis of equality, mutual respect for territorial integrity and sovereignty". ${ }^{4}$

To ensure that the trade between the two countries remains strong and continuous, the development of the very significant China-Pak Economic Corridor is under construction. It will connect Pakistan with China and the Central Asian countries via highways from Kashgar to Khunjrab and Gwadar. It will reduce the time required for transporting and trading goods, and thus decreasing overall expenditures. The most important consideration of all, in favour of recognition of Pakistan by the Chinese was the fact that Pakistan, then aspired to play a leading role among the Muslim states of the Middle East, China therefore, regarded her relationship with Pakistan as a prerequisite to a role of its own in the Middle East". 5
\end{abstract}

\section{CHINA-PAKISTAN ECONOMIC CORRIDOR:}

Trade is a residual item, a way of making up deficiencies or disposing of surplus. ${ }^{6}$ China has pursued trade relations with a number of underdeveloped countries in Asia, Africa and Latin America, including Pakistan. In many of these cases, motivation has been as much political as commercial or economic. ${ }^{7}$ It is basically a construction project which will result in the formation of many different forms of routes to ensure the continuous

\footnotetext{
${ }^{1}$ Jabri, Parvez. "Pak, China Relationship Has Glorious Past, Bright Future." Http://www.brecorder.com/pakistan/general-news/148069-pakchina-relationship-has-glorious-past-bright-future.html. Business Recorder, 10 Dec. 2013. Web. 11 Nov. 2015.

${ }^{2}$ Rais, RasoolBux. "China and Pakistan A Political Analysis of Mutual Relations.” Lahore,1977,p.7.

${ }^{3}$ Phillippe, Stern. “Ancient Pakistan and Their Civilaztion”London,1951,p111-12.

${ }^{4}$ Qutubuddin, Aziz. "Relations Between Pakistan and People's Republic of China".Karachi,p.74

${ }^{5}$ B.L, Sharma. "Pakistan China Axis"London,1967,p 185.

${ }^{6}$ Dounithorne, Andrey. “China’s Economic System” London,1967,p32.

${ }^{7}$ Eckstein, Alexander. “Communist China's Economic Growth and Foreign Trade”. New York,1966,p 4.
} 
and bountiful trade between these two major countries. According to the Board of Investment of the Prime Minister's Office Government of Pakistan,

"The China-Pakistan Economic Corridor (CPEC) is a network of Roads, Railway, Energy Infrastructure, and Pipelines with $3,000 \mathrm{~km}$ from Gwadar in Pakistan to China's western Xinjiang region - It includes a total of over US \$46 billion Investment."1

This project is expected to be completed up to 2030. It was decided that the finance for China-Pakistan Economic Corridor will be provided by both the countries, to decrease the dependence on foreign countries. Establishment of China-Pakistan Economic Corridor (CPEC) was first proposed by Chinese Premier Li Keqiang during his visit to Pakistan in May 2013.

It was announced by the Chinese government in November of 2014 , that $\$ 45.6$ billion will be spent on financing energy and infrastructure projects in Pakistan as part of the China-Pakistan Economic Corridor. ${ }^{2}$ For example, the Karakoram highway (a 1,300 km long highway from Havelian in the Abbottabad District to Thakot) project, which first began construction in 1979, will receive new attention in order to widen it and get the most out of it. The Islamabad-Hazara motorway is yet another route that the Chinese government will assist Pakistan in building. Lastly, due to the China- Pakistan Economic Corridor, the areas surrounding the pathway will be updated to match the level of development of the highway. ${ }^{3}$

\section{MOU'S SIGNED DURING THE PRESIDENT OF CHINA'S VISIT: ${ }^{4}$}

On April 20, 2015, the Chinese President Xi Jinping visited Islamabad to meet Pakistan's officials and decide on new plans of actions. Pakistan and China signed 51 MoU's, 5 of which were pertaining to the energy sector while 30 pertain to the economic development. They also decided that China will invest about $\$ 45$ billion in Pakistan to improve renewable energy, optical fiber installation, anti-terrorism, anti-narcotics, LNG, Karakoram Highway and many others.

China's president, Jinping stated, ${ }^{5}$

"The purpose of my visit is to strengthen ties with Pakistan. Like Pakistan, China also expects peace in Afghanistan. We support the efforts of Pakistan regarding terrorism." Furthermore, he added that "a new era of economic development would begin with these agreements between China and Pakistan."

As an additional bonus, both Presidents also inaugurated 8 projects after the ceremony, unveiling the following plaques:

1. Industrial and Commercial Bank of China, Lahore Branch.

2. Energization of $100 \mathrm{MW}$ solar power plants at Quad-i-Azam solar park, Bahawalpur.

3. FM 98 Dosti Channel studio PBC-CRI, Islamabad.

4. Demonstration project of DTMB Broadcasting in Pakistan.

5. China Cultural center Pakistan.

6. China-Pakistan Joint Research Center for small hydropower, Islamabad.

7. China-pakistan cross-border optical fiber cable system project.

8. Metro rail transit system on the Orange Line in Lahore.

Some of the important agreements and MOUs signed are as under:

1. Economic and technical cooperation agreement between China and Pakistan.

2. Exchange of notes of feasibility study of the demonstration project of the DTMB, on provision of anti-narcotics equipment, on provision of law enforcement equipment, and on feasibility study of Gwadar hospital.

3. MoU on provision of Chinese governmental concessional loan for second phase up-gradation of the Karakorum Highway (Havelian to Thakot), Karachi-Lahore Motorway (Multan to Sukkur), Gwadar port East Bay Expressway Project, and Gwadar international airport.

4. Protocol on banking services to agreement on trade in services.

5. MoU on provision of material for tackling climate change.

6. Framework agreement on cooperation on major communications infrastructure project.

7. MoU on cooperation between NDRC of China and Ministry of Planning Development and Reform

\footnotetext{
1"China Pakistan Economic Corridor." Board of Investment. Prime Minister's Office Government of Pakistan, 10 Nov. 2014. Web. 11 Nov. 2015. <http://boi.gov.pk/Home.aspx>.

${ }^{2}$ Progress Think Tank."China-Pakistan Economic Corridor." Progress: A Think Tank and a Sustainable Development Organization. Foundation for Progress Towards a Better Pakistan, 2015. Web. 15 Nov. 2015. <http://www.progress.org.pk/2015/07/china-pakistaneconomic-corridor/>.

3"Benefits of China-Pakistan Economic Corridor." PK Viral. N.p., 19 Apr. 2015. Web. 10 Nov. 2015. <http://www.pkviral.com/benefits-ofchina-pakistan-economic-corridor/>.

4 "Pak-China Signed 51 MOU's of worth Billion Dollars in Islamabad Today."Board of Investment. Prime Minister's Office Government of Pakistan, 20 Apr. 2015. Web. 12 Nov. 2015. <http://boi.gov.pk/ViewNews.aspx?NID=413>.

5 "Pak-China Signed 51 MOU's of worth Billion Dollars." The News Teller - Pakistan.N.p., 20 Mar. 2015. Web. 12 Nov. 2015.

$<$ http://www.thenewsteller.com/pakistan/pak-china-signed-51-mous-of-worth-billion-dollars-in-islamabad-today/13324/>.
} 
of Pakistan.

8. MoU on Pro Bono Projects in the Port of Gwadar Region.

9. MoU on establishment of China-Pakistan joint cotton bio-tech laboratory.

10. Framework agreement between the National Railway Administration, China and the Ministry of Railways, Pakistan on joint feasibility study for up-gradation of ML1 and establishment of Havelain dry port of Pakistan Railways.

11. Protocol on the establishment of China-Pakistan joint marine research center.

12. MoU on cooperation between the State Administration of Press, Publication, Radio, Films and Television of China and Ministry of Information, Broadcasting and National Heritage of Pakistan.

13. Triple party agreement between China Central Television and PTV and Pakistan Television Foundation on the re-broadcasting of CCTV-NEWS/CCTV -9 Documentary in Pakistan.

14. Protocol on establishment of sister cities relationship between:

a. Chengdu city Sichuan Province of PRC and Lahore city

b. Zhuhai city, Guangdong province and Gwadar city

c. Karamay City, XianjianUgur, and Gwadar city.

15. Framework agreement between NEA and MoPNR on Gwadar-Nawabshah LNG terminal and pipeline project.

16. Commercial contract and agreement on financing for Lahore Orange Line Metro Train Project.

17. MoU on financing for KKH up-gradation Phase-2 (Havelian to Takot), KLM, Gwadar east bay expressway, Gwadar international airport projects.

18. Financing agreement relating to the $870 \mathrm{MW}$ hydro-electric SukiKinari hydropower project between EXIM Bank of China, Industrial and Commercial Bank of China Limited and SK Hydro (Private) Limited.

19. Financing cooperation agreement between the EXIM Bank of China and Port Qasim Electric Power Company (Private) Limited (on Port Qasim 2x660MW coal-fired power plant).

20. Framework facility agreement for 720MW Karot hydropower project between China Development Bank Corporation, EXIM Bank of China and Karot Power Company (Private) Limited.

21. Term sheet of the facility for Zonergy 9x100 MW solar project in Punjab between China Development Bank Corporation, EXIM Bank of China and Zonergy Company limited.

22. Drawdown agreement on Jhimpir wind power project between UEP Wind Power (Private) Limited as borrower and China Development Bank Corporation as lender.

23. Terms and conditions in favor of Sindh Engro Coal Mining Company for Thar Block II 3.8Mt/a mining Project, Sindh province, Pakistan arranged by China Development Bank Corporation.

24. Terms and conditions in favor of EngroPowergenThar (Private) Limited, Sindh province, Pakistan for Thar Block II 2x330MW coal fired power project arranged by China Development Bank Corporation.

25. Framework agreement of Financing Cooperation in Implementing the China-Pakistan Economic Corridor between China Development Corporation and HBL.

26. MoU with respect to cooperation between Wapda and CTG.

27. MoU among PPIB, CTG, and Silk Road Fund on Development of Private Hydro Power Projects.

28. Facility operating agreement for Dawood Wind Power project between ICBC and PCC of China and HDPPL.

29. Framework agreement for promoting chinese investments and industrial parks development in Pakistan between ICBC and HBL on financial services corporation.

30. The financing term sheet agreement for Thar Block -I between ICBC, SSRL.

31. Energy strategic cooperation framework agreement between Punjab province and China Huaneng Group.

32. Framework agreement on the China Pakistan Economic Corridor Energy Project Cooperation.

33. Cooperation agreement between Sino-Sindh Resources (Pvt) Ltd and Shanghai Electric Group for Thar Coalfield Block I Coal-Power integrated Project in Pakistan.

34. Cooperation agreement for Matiyari-Lahore and Matyari (Port Qasim)-Faisalabad Transmission and Transformation Project between National Transmission Distribution Company (NTDC) and National Grid of China.

35. IA on Port Qasim Coal fired Power Plant between Power China and GoP.

36. Cooperation and Facility Agreement for:

a. theSahiwal Coal-fired Power Plant Project between industrial and Commercial Bank of China Limited, Huaneng Shandong Electricity limited and Shandong Ruyi Group.

b. Hubco Coal-fired Power Plant Project between CPIH and Hubco Power Company

c. Salt Range Coal-fired Power Project between CMEC and Punjab Government. 
37. MoU between NUML Pakistan and Xinjiang Normal University, Urumqi China for Cooperation on Higher Education.

38. Agreement on collaboration on establishment of NUML International Center of education (NICE) between NUML Pakistan and Xinjiang Normal University, Urumqi, China.

The China-Pak Economic Corridor will serve as a much needed transformational positive revolution in bringing many solutions to the country's most pressing issues involving energy and infrastructure among other things. ${ }^{1}$ According to the Federal Minister Planning, Development \& Reform, AhsanIqbal, stated,

"CPEC will help overcome the energy crisis, increasing power generation capacity and fulfilling the electricity needs of the country. Chinese assistance will alsohelp to construct LNG pipeline to supply gas to power stations. Thar that is known for drought would emerge energy capital of the country that would ultimately provide diverse opportunities of employment and growth in the backward areas of interior Sindh. The development of Gawadar port \& airport and construction of eastern, western and central alignments would connect all the provinces and regions of the country and would turn the country into manufacturing expert." ${ }^{2}$

\section{CHINA PAKISTAN CORRIDOR IS A FATE CHANGER:}

\section{BENEFITS FOR PAKISTAN:}

The friendship between the two nations is not based upon expediency. ${ }^{3}$ As part of the agreement China has vowed to invest up to $\$ 45.6$ billion in Pakistan in order to jumpstart its economy and solve its major energy issues.

According to "Senator Hussain, chairman of the Pakistan Parliament's Defense Committee, in an interview with Chinese media,

'CPEC is a corridor of unity, uniting the people of Pakistan, the provinces of Pakistan, all the regions and areas of Pakistan in a quest for prosperity through different projects.'

Hussain [continued by saying that] Gwadar port in Pakistan's southern province of Baluchistan, will create a new situation in the province as well as in Pakistan, and a number of projects like road links, industrial parks, power projects, the rail links and fiber optics will directly benefit all people of the country."

The multiple improvements of the infrastructure will mean easier access throughout and out of Pakistan. This will benefit the country in two ways: one is that trade will become easier, cheaper, and more efficient for Pakistan with its surrounding countries thus improving the trading aspect of its economy. ${ }^{5}$

By contributing to bettering the energy sector of Pakistan, China is pretty much guaranteeing Pakistan an entrance into an entirely new level of technological advancement. Energy and electricity is at the root of every other type of advancement: educational, political, economic, and social; thus by improving the base, Pakistan will be able to build the rest on top of the firm foundation. ${ }^{6}$

\section{BENEFITS FOR CHINA: ${ }^{7}$}

For China, the main benefit of the China-Pakistan Economic Corridor comes in two tremendously important ways. One of which is that the new route will be a shorter more efficient way for oil to be transported from the Middle East and Africa to China in order to fulfil China's enormous daily energy needs. The other is that through the new route, there is a greater chance for trade to flourish even more because of the ease of access between the two geographical areas that will be connected through the roads and pathways.

China is home to a very large population, all of whom are working towards bettering the Chinese economy through their daily jobs, expenditures, and businesses. A great deal of them rely heavily on energy sources in order to conduct their part in the society and economy, thus China has a great demand for oil, as cheap as they can get it. This means that their cost for importing oil is at an extreme level, but there is nothing they can do about because oil is one resource that they do not have, but desperately need for all their people. Energy is at the base of every single one of China's projects, or the world's for that matter, and without they cannot even imagine progressing in their economy.

Oil imports are very important for China, however, another very important benefit that China will gain from

\footnotetext{
${ }^{1}$ Syed, Anwer. "China and Pakistan Diplomacy” United Staes, 1974,p 54

${ }^{2}$ Malik, Haji Ahmed. "Early Harvest Projects of CPEC Will Be Completed by Dec. 2017, Says AhsanIqbal." Ministry of Planning, Development, and Reform.Pakistan's Ministry of Planning, Development, and Reform, 9 Sept. 2015.Web. 15 Nov. 2015. $<$ http://www.pc.gov.pk/?p=4575>.

${ }^{3}$ Arif, K. "China Pakistan Relations"1984,Lahore,p 101

4 "China-Pakistan Economic Corridor to Benefit All Regions." The Nation News.INP., 12 June 2015. Web. 12 Nov. 2015.

$<$ http://nation.com.pk/national/12-Jun-2015/china-pakistan-economic-corridor-to-benefit-all-regions>

5 "China Quarterly" April 5,1965.

${ }^{6}$ Cohen, G.M. “The Asian Countries” 1967,p 55.

${ }^{7}$ Salman, Ali. "Pakistan-China Economic Corridor: A Cost-benefit Analysis." The Express Tribune with the International New York Times, 3

May 2015. Web. 14 Nov. 2015. <http://tribune.com.pk/story/880259/pakistan-china-economic-corridor-a-cost-benefit-analysis/>.
} 
this deal has to do with the fact that "half of Chinese exports are destined on its Western side, so it will also gain tremendously by saving on its containerised traffic costs". ${ }^{1}$

\section{CONCLUSION AND ANALYSIS:}

Contemporary changing patterns of international politics will draw attention of the world's leaders to look at the recent change in the region of South Asia and its impact on the rest of the world. Just after the global recession after September 11, 2001, China did not face the challenges which the North American world faced because of its establishment in the political economy and public policies towards actual grooming of economic zones and support to its people. In response to the governments support, Chinese people, whether they live in Chinese territory or any other part of the world, believe that the stability in the political economy of China will always maintain the positive image of the Chinese nation in the rest of the world to defeat the Uni-polar system after the war between the former USSR and USA. Undoubtedly, Pakistan's rival, India has shifted its political role to support the USA and expand its business and allow US to expand businesses in the Indian Territory which might have previously been a challenge to the neighbour country of China. Realizing this fact, Chinese leadership decided to motivate its nation and decision makers to encourage and support the China-Pak Economic Corridor, which is obviously a great message in world politics regarding mutual understanding between China and Pakistan, economic growth, and war against terrorism. Furthermore, this effort will create a meaningful message of peace and tolerance as well as restoration of the message of the United Nations for peaceful settlement and cooperation among the nations. This effort would also be a source of inspiration for promoting socio-political relations as well as intercultural communications among nations.

\section{REFERENCES:}

1. Jabri, ParvezPak, China Relationship Has Glorious Past, Bright FutureHttp://www.brecorder.com/pakistan/general-news/148069-pak-china-relationship-has-glorious-pastbright-future.html. Business Recorder, 10 Dec. 2013. Web. 11 Nov. 2015.

2. Rais, RasoolBux. China and Pakistan A Political Analysis of Mutual Relations (Lahore,1977),7.

3. Phillippe, Stern. Ancient Pakistan and Their Civilaztion (London,1951),111-12.

4. Qutubuddin, Aziz. Relations Between Pakistan and People's Republic of China (Karachi),74

5. B.L, Sharma. Pakistan China Axis (London,1967),185.

6. Dounithorne, Andrey. China's Economic System (London,1967),32.

7. Eckstein, Alexander. Communist China's Economic Growth and Foreign Trade (New York,1966),4.

8. Syed, Anwer. China and Pakistan Diplomacy (United Staes, 1974), 54

9. Arif, K. China Pakistan Relations (1984,Lahore),101.

10. "Pak-China" China Quarterly, April 5,1965.

11. Cohen, G.M. The Asian Countries(1967),55.

12. "The Journal of Commerce." Langshire, December 28,1968.

13. "China Pakistan Economic Corridor." Board of Investment. Prime Minister's Office Government of Pakistan, 10 Nov. 2014. Web. 11 Nov. 2015. <http://boi.gov.pk/Home.aspx>.

14. Raja, AsifHaroon. "China-Pakistan Energy Corridor." Pak Tribune - Pakistan News Service. N.p., 1 May 2015. Web. 10 Nov. 2015. <http://paktribune.com/articles/China-Pakistan-Energy-Corridor-243238.html>.

15. Progress Think Tank. "China-Pakistan Economic Corridor." Progress: A Think Tank and a Sustainable Development Organization. Foundation for Progress Towards a Better Pakistan, 2015. Web. 15 Nov. 2015. $<\mathrm{http}: / /$ www.progress.org.pk/2015/07/china-pakistan-economic-corridor/>.

16. "Benefits of China-Pakistan Economic Corridor." PK Viral. N.p., 19 Apr. 2015. Web. 10 Nov. 2015. $<$ http://www.pkviral.com/benefits-of-china-pakistan-economic-corridor/>.

17. "Pak-China Signed 51 MOU's of worth Billion Dollars in Islamabad Today."Board of Investment. Prime Minister's Office Government of Pakistan, 20 Apr. 2015. Web. 12 Nov. 2015. $<$ http://boi.gov.pk/ViewNews.aspx?NID=413>.

18. "Pak-China Signed 51 MOU's of worth Billion Dollars." The News Teller - Pakistan. N.p., 20 Mar. 2015. Web. 12 Nov. 2015. <http://www.thenewsteller.com/pakistan/pak-china-signed-51-mous-of-worth-billiondollars-in-islamabad-today/13324/>.

19. Malik, Haji Ahmed. "Early Harvest Projects of CPEC Will Be Completed by Dec. 2017, Says AhsanIqbal." Ministry of Planning, Development, and Reform. Pakistan's Ministry of Planning, Development, and Reform, 9 Sept. 2015. Web. 15 Nov. 2015. <http://www.pc.gov.pk/?p=4575>.

20. "China-Pakistan Economic Corridor to Benefit All Regions." The Nation News. INP., 12 June 2015. Web. 12 Nov. 2015. <http://nation.com.pk/national/12-Jun-2015/china-pakistan-economic-corridor-to-benefit-allregions $>$

\footnotetext{
1“The Journal of Commerce.”Langshire, December 28,1968.
} 
21. Salman, Ali. "Pakistan-China Economic Corridor: A Cost-benefit Analysis." The Express Tribune with the International New York Times, 3 May 2015. Web. 14 Nov. 2015. $<$ http://tribune.com.pk/story/880259/pakistan-china-economic-corridor-a-cost-benefit-analysis/>. 